\title{
Feeding oregano oil and its main component carvacrol does not affect ruminal fermentation, nutrient utilization, methane emissions, milk production, or milk fatty acid composition of dairy cows
}

\section{Benchaar* (1)}

Agriculture and Agri-Food Canada, Sherbrooke Research and Development Centre, 2000 College Street, Sherbrooke, QC, Canada J1M 0C8

\begin{abstract}
Because of their antimicrobial properties, essential oils and their components have been suggested as alternatives to other antimicrobials (e.g., monensin) that are commonly fed to ruminants to improve nutrient utilization and enhance feed efficiency and milk performance. In this study, we evaluated the potential of oregano oil and its main component (carvacrol) as rumen modifiers. For this purpose, 8 ruminally cannulated lactating dairy cows $(92 \pm 11 \mathrm{~d}$ in milk, $36.5 \pm 7.6 \mathrm{~kg}$ of milk yield, and $703 \pm 74 \mathrm{~kg}$ of body weight) were used in a double $4 \times 4$ Latin square (28-d periods). Cows were fed 1 of the 4 following treatments: (1) control (CTL, no additive); (2) monensin [MON, $24 \mathrm{mg} / \mathrm{kg}$ of dry matter (DM)]; (3) oregano oil (ORE, $50 \mathrm{mg} / \mathrm{kg}$ of DM); and (4) carvacrol (CAR, $50 \mathrm{mg} / \mathrm{kg}$ of DM). Cows were fed (ad libitum intake) a total mixed ration consisting of $60 \%$ forages (corn silage and alfalfa silage) and $40 \%$ concentrates, on a DM basis. Feeding ORE and CAR had no effect on nutrient total-tract apparent digestibility, $\mathrm{N}$ utilization, rumen fermentation (i.e., $\mathrm{pH}$, ammonia, volatile fatty acids), protozoa counts, or milk performance. Feeding MON increased the molar proportion of propionate and tended to increase totaltract apparent digestibility of crude protein. None of the feed additives evaluated affected enteric methane production $(491 \mathrm{~g} / \mathrm{d}, 21.1 \mathrm{~g} / \mathrm{kg}$ of DM intake, $6.14 \%$ of gross energy intake on average). Milk fatty acid composition was not changed by ORE or CAR, but MON increased the proportion of trans-10 18:1, an intermediate of ruminal biohydrogenation. Thus, when included at $50 \mathrm{mg} / \mathrm{kg}$ of dietary dry matter, neither oregano oil nor carvacrol favorably altered rumen fermentation, improved nutrient utilization or milk performance, or mitigated enteric methane emissions in dairy cows.
\end{abstract}

Received July 8, 2019.

Accepted September 30, 2019.

*Corresponding author: chaouki.benchaar@canada.ca
Key words: essential oils, nutrient utilization, milk production, milk fatty acid, methane production

\section{INTRODUCTION}

Because of increasing public pressure to decrease the use of antimicrobials in livestock production and the regulations that ban the use of these substances in Europe (European Union, 2003), scientists and the livestock feed industry have been actively working to find alternatives to antimicrobials (Benchaar et al., 2008, 2009). Among these alternatives, essential oils (EO) and their compounds have attracted much attention because of their antimicrobial properties that may modulate rumen fermentation (Benchaar and Greathead, 2011). Essential oils (e.g., oregano oil) with high concentrations of phenolic compounds (e.g., carvacrol) have been evaluated, mainly in vitro, as rumen fermentation modifiers (see reviews by Calsamiglia et al., 2007 and Cobellis et al., 2016). Several short-term in vitro studies have shown that oregano oil and its main component carvacrol affect $\mathrm{N}$ metabolism via the reduction of protein degradation and ammonia production (Benchaar et al., 2008). Oregano oil and carvacrol have also been investigated extensively for their potential to inhibit ruminal methanogenesis in vitro (Benchaar and Greathead, 2011; Cobellis et al., 2016). For instance, using in vitro batch cultures of ruminal fluid, Macheboeuf et al. (2008) observed that oregano oil decreased methane production (up to a $98 \%$ decrease). In the same study, the authors reported lower antimethanogenic activity of carvacrol, suggesting that other components present in lower concentrations in oregano oil may have acted antagonistically with carvacrol, thereby attenuating the antimethanogenic properties of oregano oil. However, because of the limitations of in vitro techniques (i.e., short-term incubation, buffered medium, inability to replicate the diversity and viability of the microbial population of the rumen), data should be interpreted with caution. Furthermore, the high concentrations used in vitro are impractical for in 
vivo conditions; thus, the effects observed in vitro may not be reliable for in vivo applications (Beauchemin et al., 2009; Benchaar and Greathead, 2011).

Few in vivo studies have investigated the use of oregano oil in dairy cows and, to the best of our knowledge, no studies have been published on the potential use of carvacrol as a feed additive in dairy cow diets. In a Danish study, Lejonklev et al. (2016) observed no changes in DMI, milk production, or enteric $\mathrm{CH}_{4}$ emissions in dairy cows $(\mathrm{n}=3)$ fed high concentrations of oregano oil for $1 \mathrm{~d}(0.2$ and $1.0 \mathrm{~g} / \mathrm{kg}$ of DM, corresponding to intakes of 4.3 and $22.4 \mathrm{~g} / \mathrm{d}$, respectively). Tekippe et al. (2011) and Hristov et al. (2013) assessed the effects of oregano leaves on rumen fermentation, nutrient digestibility, $\mathrm{N}$ excretion, $\mathrm{CH}_{4}$ production, and milk performance of dairy cows. In Tekippe et al. (2011), ruminal pulse dosing of $500 \mathrm{~g} / \mathrm{d}$ of oregano leaves had no effect on DMI, milk yield, VFA (total and individual) concentrations, protozoa number, nutrient digestibility, or $\mathrm{N}$ excretion. Enteric $\mathrm{CH}_{4}$ production measured within $8 \mathrm{~h}$ after feeding using the $\mathrm{SF}_{6}$ tracer technique and sampling the rumen headspace decreased with oregano oil supplementation. In a subsequent study by the same group, supplementation of oregano leaves $(250,500$, and $750 \mathrm{~g} / \mathrm{d}$ ) decreased DMI but had no effect on nutrient digestibility, rumen fermentation characteristics, protozoa, $\mathrm{N}$ excretion, or milk fatty acid (FA) profile (Hristov et al., 2013). Using the same methodology as Tekippe et al. (2011), Hristov et al. (2013) reported a decrease in enteric $\mathrm{CH}_{4}$ production in cows fed increasing amounts of oregano leaves $(250,500$, and 750 $\mathrm{g} / \mathrm{d})$. In both studies, inhibition of $\mathrm{CH}_{4}$ production was not associated with a shift in rumen fermentation toward propionogenesis and had no effect on protozoa or Methanobrevibacter, the predominant Archaea genus in the rumen. All of these factors are known to influence ruminal methanogenesis (Beauchemin et al., 2009). Furthermore, given that $\mathrm{CH}_{4}$ was measured only within $8 \mathrm{~h}$ after feeding, it is not certain that the inhibitory effect of oregano leaves would have persisted during the remaining $16 \mathrm{~h}$ of the feeding cycle (Tekippe et al., 2011; Hristov et al., 2013). More recently, Kolling et al. (2018) fed oregano extract $(10 \mathrm{~g} / \mathrm{d})$ to dairy cows and reported no change in DMI, nutrient digestibility, milk yield, or milk composition. During the gas measurement period in the respiration chambers, Kolling et al. (2018) observed a decline in enteric $\mathrm{CH}_{4}$ production ( $\mathrm{g} /$ $\mathrm{kg}$ of DMI) associated with a tendency for an increase in DMI.

The effects of oregano leaves or extract on enteric $\mathrm{CH}_{4}$ observed by Tekippe et al. (2011), Hristov et al. (2013), and Kolling et al. (2018) cannot be attributed solely to the EO fraction or its main component car- vacrol, or both (up to $90.8 \%$ of the oil; Tekippe et al., 2011) contained in the oregano supplement. In fact, compounds other than EO may have contributed to the inhibitory effect of oregano leaves or extract. Oregano may also contain other substances such as lipids, FA, phenolic, quinones, and flavonoids (Kerala, 2001; Skoula and Harborne, 2002; Skoula et al., 2008). Many of these substances, in particular flavonoids, have been shown to exhibit antimicrobial activities (Baričevič and Bartol, 2002; Cushnie and Lamb, 2005; Skoula et al., 2008 ) and thus, may also inhibit rumen methanogens. In contrast, in the studies by Tekippe et al. (2011) and Hristov et al. (2013), the concentrations of EO and carvacrol provided by oregano leaves ranged from 4 to 12 $\mathrm{g} / \mathrm{d}$ (140 to $445 \mathrm{mg} / \mathrm{kg}$ of DMI) and 3 to $9 \mathrm{~g} / \mathrm{d}$ of carvacrol (110 to $350 \mathrm{mg} / \mathrm{kg}$ of DMI), respectively. Such doses of EO are higher than the levels recommended by feed additive suppliers and the doses reported in the literature (Benchaar et al., 2009; Cobellis et al., 2016) and are not cost effective if oregano oil or carvacrol is used as a feed additive in dairy cow diets.

Based on these considerations, the aim of this study was to evaluate the potential of using oregano oil and its main constituent carvacrol as feed additives in dairy cow diets to modulate rumen fermentation, improve feed efficiency, reduce $\mathrm{N}$ excretion, and mitigate enteric $\mathrm{CH}_{4}$ production. Accordingly, the specific goals were to determine the effects of oregano oil and carvacrol on feed intake, ruminal fermentation, nutrient total-tract apparent digestibility, $\mathrm{N}$ excretion, $\mathrm{CH}_{4}$ production, milk production, and milk FA composition.

\section{MATERIALS AND METHODS}

\section{Cows, Experimental Design, and Diets}

Eight multiparous cows fitted with rumen cannulas (10 cm i.d.; Bar Diamond Inc., Parma, ID) were used in this study. The experimental design was a replicated $4 \times 4$ Latin square design balanced for residual effects (Cochran and Cox, 1957). At the start of the trial, cows averaged (mean $\pm \mathrm{SD}$ ) $92 \pm 11 \mathrm{DIM}, 36.5 \pm 7.6 \mathrm{~kg}$ of milk yield, and $703 \pm 74 \mathrm{~kg}$ of BW. Cows were kept in individual tie stalls and had free access to water for the duration of the experiment. They were fed the same basal diet as a TMR (Table 1). Experimental treatments were (1) TMR with no additive (CTL); (2) TMR supplemented with monensin (MON; $24 \mathrm{mg} /$ $\mathrm{kg}$ ); (3) TMR supplemented with oregano oil (ORE; $50 \mathrm{mg} / \mathrm{kg}$ ); and (4) TMR supplemented with carvacrol (CAR; $50 \mathrm{mg} / \mathrm{kg}$ ).

Oregano oil (containing $70 \%$ carvacrol) and CAR (98\% purity) were from Phodé S.A. (Albi, France); mo- 
Table 1. Ingredient and chemical composition of the TMR

\begin{tabular}{|c|c|}
\hline Item ( $\%$ of DM, unless otherwise noted) & Value \\
\hline \multicolumn{2}{|l|}{ Ingredient } \\
\hline Alfalfa silage & 31.4 \\
\hline Corn silage & 28.7 \\
\hline Corn grain, rolled & 21.7 \\
\hline Soybean meal, $48 \%$ solvent-extracted & 7.64 \\
\hline Beet pulp, dehydrated & 5.61 \\
\hline Top supplement ${ }^{1}$ & 2.63 \\
\hline Mineral and vitamin supplement ${ }^{2}$ & 2.04 \\
\hline Calcium carbonate & 0.25 \\
\hline \multicolumn{2}{|l|}{ Chemical composition } \\
\hline $\mathrm{OM}$ & 92.6 \\
\hline $\mathrm{CP}$ & 17.9 \\
\hline $\mathrm{NDF}$ & 31.3 \\
\hline $\mathrm{ADF}$ & 20.8 \\
\hline Starch & 20.0 \\
\hline Ether extract & 2.66 \\
\hline Gross energy (Mcal/kg of DM) & 4.43 \\
\hline $\mathrm{NE}_{\mathrm{L}}(\mathrm{Mcal} / \mathrm{kg} \text { of DM})^{3}$ & 1.60 \\
\hline \multicolumn{2}{|l|}{ Fatty acid (g/kg of DM) } \\
\hline $14: 0$ & 0.09 \\
\hline $16: 0$ & 5.26 \\
\hline cis-9 16:1 & 0.06 \\
\hline 18:0 & 0.83 \\
\hline cis-9 18:1 & 5.49 \\
\hline cis-11 18:1 & 0.23 \\
\hline cis-9,cis-12 18:2 & 12.2 \\
\hline cis-9,cis-12,cis-15 18:3 & 3.76 \\
\hline $20: 0$ & 0.20 \\
\hline Total & 28.1 \\
\hline
\end{tabular}

${ }^{1}$ Contained $20.8 \%$ corn gluten meal, $28.3 \%$ soybean meal Trituro (SoyaExcel, Saint-Charles-Sur-Richelieu, QC, Canada), 16.7\% canola meal, $34.2 \%$ dried corn distillers grains.

${ }^{2}$ Contained $12.5 \%$ Ca, $6.80 \%$ P, $6.81 \% \mathrm{Mg}, 2.49 \% \mathrm{~S}, 7.72 \% \mathrm{Na}, 1.97 \%$ $\mathrm{K}, 2,877 \mathrm{mg} / \mathrm{kg} \mathrm{Fe}, 3,777 \mathrm{mg} / \mathrm{kg} \mathrm{Zn}, 620 \mathrm{mg} / \mathrm{kg} \mathrm{Cu}, 2,520 \mathrm{mg} / \mathrm{kg} \mathrm{Mn}$, $96 \mathrm{mg} / \mathrm{kg} \mathrm{I}, 83 \mathrm{mg} / \mathrm{kg} \mathrm{Co}, 27.8 \mathrm{mg} / \mathrm{kg} \mathrm{Se}, 628,000 \mathrm{IU} / \mathrm{kg}$ of vitamin A, $81,000 \mathrm{UI} / \mathrm{kg}$ of vitamin D, and $3,739 \mathrm{IU} / \mathrm{kg}$ of vitamin E.

${ }^{3}$ Calculated according to NRC (2001).

nensin (Rumensin 80) was from Elanco Animal Health (Guelph, ON, Canada). Each feed additive was premixed with a portion of the concentrate and included in the TMR to obtain the targeted concentration. The diets were offered ad libitum (5\% refusals on an asfed basis). Adaptation to experimental treatments was from d 1 to 14, ruminal fluid sampling occurred on d 14 and d 28, $\mathrm{CH}_{4}$ production monitoring from d 19 to 25 , and sampling of milk, feces, and urine from d 20 to 26 . The Institutional Animal Care Committee of the Sherbrooke Research and Development Centre (Sherbrooke, QC, Canada) approved the animal procedures and all cows were cared for in accordance with the guidelines of the Canadian Council on Animal Care (2009).

\section{Intake, Total-Tract Apparent Digestibility, and $\mathrm{N}$ Excretion}

Cows were fed daily at 0900 and 1930 h. Daily feed intake was determined by weighing the amounts of feed offered and orts. Feed samples (i.e., TMR, ingredients, orts) were collected daily and kept at $-20^{\circ} \mathrm{C}$. They were later thawed, composited by cow within period, freezedried, and ground through a 1-mm screen (standard model 4; Arthur H. Thomas, Philadelphia, PA) for the analysis of DM, OM, total N, NDF, ADF, starch, ether extract, gross energy $(\mathbf{G E})$, and FA.

Feces and urine were collected separately using harnesses and tubes, weighed, and sampled proportionally ( $2 \%$, on a fresh matter basis), as described in Benchaar et al. (2013). The daily samples were stored at $-20^{\circ} \mathrm{C}$ and later thawed and composited by cow within period. Fecal samples were freeze-dried and ground through a 1-mm screen for the analysis of DM, OM, total N, NDF, starch, and GE concentrations. Urine samples were frozen at $-20^{\circ} \mathrm{C}$ until analyzed for total $\mathrm{N}$.

\section{Ruminal Fermentation Characteristics and Protozoa Enumeration}

Ruminal pH, VFA, and ammonia were measured in ruminal fluid collected before $(0 \mathrm{~h})$ and at $1,2,4$, 6 , and $8 \mathrm{~h}$ after the a.m. feeding. For this purpose, ruminal fluid $(\sim 250 \mathrm{~mL})$ was collected from the anterior dorsal, anterior ventral, medium ventral, posterior dorsal, and posterior ventral locations within the rumen using a $50-\mathrm{mL}$ syringe screwed to a stainless tube ending with a probe covered by a fine metal mesh (RT Rumen Fluid Collection Tube, Bar Diamond Inc.). Ruminal $\mathrm{pH}$ was measured immediately after sampling (Accumet pH meter; Fisher Scientific, Montreal, QC, Canada). Samples $(15 \mathrm{~mL})$ were stored at $-20^{\circ} \mathrm{C}$ for the determination of VFA. Ammonia was measured in samples conserved with 50\% sulfuric acid and stored at $-20^{\circ} \mathrm{C}$ until analysis.

Protozoa enumeration was performed as described in Benchaar et al. (2013). Ruminal content ( $\sim 1$ L) was collected $4 \mathrm{~h}$ after the a.m. feeding and squeezed through 4 layers of cheesecloth. Samples $(5 \mathrm{~mL})$ of the filtered ruminal fluid were preserved with methyl green formalin-saline solution $(5 \mathrm{~mL})$ for later enumeration of protozoa (Ogimoto and Imai, 1981) using a counting chamber (Neubauer Improved Bright-Line counting cell, 0.1-mm depth; Hausser Scientific, Horsham, PA).

\section{Milk Production and Milk Composition}

Cows were milked daily at 0700 and $1900 \mathrm{~h}$, and milk production was measured and recorded at each milking. Milk samples were taken at each milking, preserved with 2-bromo-2-nitropropan-1,3-diol, and shipped to Valacta (Ste-Anne-de-Bellevue, QC, Canada) for analysis of milk components (i.e., fat, protein, lactose) 
and MUN. Samples pooled from 4 consecutive milkings proportionally to milk yield were frozen at $-80^{\circ} \mathrm{C}$ for the determination of milk FA composition.

\section{Enteric Methane Production}

Enteric $\mathrm{CH}_{4}$ production was measured using the sulfur hexafluoride $\left(\mathrm{SF}_{6}\right)$ tracer technique (Johnson et al., 1994) as described in McGinn et al. (2006). Briefly, at the start of the trial, a calibrated permeation tube containing $\mathrm{SF}_{6}(4.479 \pm 0.282 \mathrm{mg} / \mathrm{d})$ was placed into the rumen of each cow and remained throughout the duration of the experiment. Breath samples of each cow were collected daily (d 19 to 25 ) in an evacuated canister $(\sim 2 \mathrm{~L})$ through a tube placed near the nostrils of the cow. After $24 \mathrm{~h}$, samples $(\mathrm{n}=3 ; 20 \mathrm{~mL} /$ sample) were collected from the canister and kept in evacuated Exetainers (Labco Ltd., Buckinghamshire, UK) for the analysis of $\mathrm{CH}_{4}$ and $\mathrm{SF}_{6}$. The canisters were changed every day before the a.m. feeding. Daily background concentrations of $\mathrm{CH}_{4}$ and $\mathrm{SF}_{6}$ in the barn were determined by placing canisters in different locations. Production of $\mathrm{CH}_{4}$ of each cow was calculated as described in McGinn et al. (2006).

\section{Chemical Analyses}

Dry matter was measured at $100^{\circ} \mathrm{C}$ using a vacuum oven overnight (AOAC International, 2005; method 934.01), $\mathrm{OM}$ by incineration at $550^{\circ} \mathrm{C}$ overnight in a muffle furnace (AOAC International, 2005; method 942.05), and total $\mathrm{N}$ according to the macro-Kjeldahl procedure (AOAC, 2005; method 954.01). The NDF was determined according to Van Soest et al. (1991) with the inclusion of sodium sulfite and heat stable $\alpha$-amylase. The ADF was determined according to AOAC International (2005; method 973.18). The NDF and ADF procedures were adapted for use in an Ankom200 Fiber Analyzer (Ankom Technology Corp., Macedon, NY). Starch was determined colorimetrically according to the procedure described in AOAC International (2005; method 996.11). Ether extract was determined according to AOAC International (2005; method 920.39) using the Soxtec 2050 extraction system (Foss, Höganäs, Sweden). Gross energy was determined using an adiabatic bomb calorimeter (model 6200, Parr Instrument Company, Moline, IL). Total $\mathrm{N}$ in urine was determined by micro-Kjeldahl analysis (AOAC International, 2005; method 960.52). Volatile fatty acids and ammonia were determined by gas chromatography (Hewlett-Packard Labs, Palo Alto, CA) and according to the method of Weatherburn (1967), respectively, as described in Benchaar (2016). Milk concentrations of true protein, fat, lactose, and urea $\mathrm{N}$ were analyzed by infrared spectroscopy (MilkoScan FT 6000; Foss Electric, Hillerød, Denmark).

For the analysis of FA in milk, FA were transmethlyated and FAME were analyzed by GC (HP 5890A Series II, Hewlett Packard, Palo Alto, CA) as previously described in Chouinard et al. (1997) and Farnworth et al. (2007). Dietary FA were analyzed according to the technique of Sukhija and Palmquist (1988).

Methane and $\mathrm{SF}_{6}$ were determined by chromatography as described in detail in Benchaar (2016). The GC (model CP-3800, Varian Inc., St-Laurent, QC, Canada) was equipped with a flame-ionization detector fitted with a column silica plot FS $(30 \mathrm{~m} \times 0.32 \mathrm{~mm})$ for $\mathrm{CH}_{4}$ analysis, and with an electron capture detector fitted with a Hayesep D stainless steel column $(2 \mathrm{~m} \times 2 \mathrm{~mm}$; 80-100 mesh) for $\mathrm{SF}_{6}$ analysis. Both columns were from Varian Inc. (Lake Forest, CA).

\section{Statistical Analyses}

All data were analyzed as replicated $4 \times 4$ Latin square design using the MIXED procedure of SAS (SAS Institute Inc., Cary, NC). Data of DMI, milk production, milk composition, digestibility, and $\mathrm{CH}_{4}$ production were averaged across days and analyzed using the following model:

$$
Y_{i j k}=\mu+A_{i}+P_{j}+T_{k}+e_{i j k}
$$

where $Y_{i j k}=$ dependent variable; $\mu=$ overall mean; $A_{i}$ $=$ random effect of cow $(i=1$ to 8$) ; P_{j}=$ fixed effect of period $(j=1,2,3,4) ; T_{k}=$ fixed effect of treatment (CTL, MON, ORE, CAR); and $e_{i j k}=$ residual error.

Data collected at different time intervals (i.e., $\mathrm{pH}$, VFA, ammonia) were analyzed as repeated measures the using the following model:

$$
Y_{i j k l m}=\mu+A_{i}+P_{j}+T_{k}+H_{l}+T \times H_{k l}+e_{i j k l l},
$$

where $H_{l}=$ fixed effect of sampling time $(0,1,2,4,6,8$ h), $T \times H_{k l}$ is the fixed effect of sampling time $\times$ treatment interaction, and other terms are as defined above.

Statistical differences were declared significant at $P$ $\leq 0.05$ and tendencies at $0.05<P \leq 0.10$ using the Tukey correction test for multiple comparisons among treatments.

\section{RESULTS}

\section{DMI, Total-Tract Apparent Digestibility, and $\mathbf{N}$ Excretion}

Data of DMI, nutrient digestibility and $\mathrm{N}$ excretion are shown in Table 2. Diet supplementation with MON, 
Table 2. Dry matter intake, nutrient total-tract apparent digestibility, and $\mathrm{N}$ excretion in lactating cows fed a TMR without supplementation (control, CTL), or supplemented with monensin (MON), oregano oil (ORE), or carvacrol (CAR)

\begin{tabular}{lcccccc}
\hline & \multicolumn{9}{c}{ Treatment } & & \\
\cline { 2 - 5 } Item & CTL & MON & ORE & CAR & SEM & $P$-value \\
\hline DMI (kg/d) & 23.8 & 23.3 & 24.2 & 23.7 & 0.45 & 0.55 \\
Digestibility (\%) & 68.1 & 68.8 & 68.4 & 68.3 & 0.43 & 0.73 \\
DM & 69.6 & 70.3 & 69.8 & 69.7 & 0.38 & 0.50 \\
OM & $66.6 \dagger$ & $68.3 \dagger$ & 67.2 & 66.7 & 0.50 & 0.10 \\
CP & 50.3 & 50.6 & 49.6 & 51.8 & 0.98 & 0.46 \\
NDF & 66.5 & 67.3 & 66.7 & 66.6 & 0.39 & 0.53 \\
Gross energy & & & & & & \\
Excretion (g/d) & 229 & 212 & 229 & 225 & 5.4 & 0.12 \\
Feces & 215 & 214 & 215 & 221 & 5.4 & 0.76 \\
Urine & 444 & 426 & 444 & 446 & 9.7 & 0.42 \\
Total & & & & & & \\
\hline
\end{tabular}

$\dagger P=0.10$ : MON vs. CTL.

ORE, and CAR had no effect on DMI $(23.8 \mathrm{~kg} / \mathrm{d})$, total-tract apparent digestibility of DM (68.4\%), OM $(69.9 \%)$, NDF $(50.6 \%)$, or GE $(66.8 \%)$. Total-tract apparent digestibility of $\mathrm{CP}$ tended $(P=0.10)$ to be higher for cows fed MON than for cows fed CTL (68.3 vs. $66.6 \%)$. The inclusion of the feed additives in the diet had no effect on $\mathrm{N}$ intake $(683 \mathrm{~g} / \mathrm{d})$ or on excretion of $\mathrm{N}$ in feces $(224 \mathrm{~g} / \mathrm{d})$ or urine $(216 \mathrm{~g} / \mathrm{d})$. Similarly, total $\mathrm{N}$ excretion (i.e., sum of fecal and urinary $\mathrm{N}$ ) was not changed by experimental treatment and averaged $440 \mathrm{~g} / \mathrm{d}$.

\section{Ruminal Fermentation Characteristics and Protozoa}

The effects of experimental treatments on ruminal fermentation characteristics and protozoa are shown in Table 3. Neither ruminal $\mathrm{pH}$ (6.20, on average) nor total VFA concentration (141.9 $\mathrm{m} M$, on average) was changed by feeding cows MON, ORE, or CAR. Molar proportions of acetate $(61.5 \mathrm{~mol} / 100 \mathrm{~mol})$, butyrate $(12.5 \mathrm{~mol} / 100 \mathrm{~mol})$, branched-chain VFA (2.58 $\mathrm{mol} / 100 \mathrm{~mol})$, and caproate $(0.60 \mathrm{~mol} / 100 \mathrm{~mol})$ were not affected by the inclusion of feed additives in the diet. The molar proportion of propionate was higher for cows fed MON than for cows fed CTL (22.6 vs. 20.8 $\mathrm{mol} / 100 \mathrm{~mol}$ ). Consequently, the acetate-to-propionate ratio was lower $(P<0.05)$ for cows fed MON than for cows fed CTL (2.71 vs. 3.03). The molar proportion of propionate tended to be lower for cows fed ORE $(P$ $=0.10)$ and $\mathrm{CAR}(P=0.09)$ than for cows fed MON (21.1 and 21.0 vs. 22.6\%). Ammonia concentration (7.71 $\mathrm{m} M$, on average) and protozoa count (7.61 $\log _{10} /$ $\mathrm{mL}$, on average) were similar among cows.

Table 3. Ruminal fermentation characteristics and protozoa counts of lactating cows fed a TMR without supplementation (control, CTL), or supplemented with monensin (MON), oregano oil (ORE), or carvacrol (CAR)

\begin{tabular}{lcccccc}
\hline & \multicolumn{7}{c}{ Treatment } & & \\
\cline { 2 - 5 } Item & CTL & MON & ORE & CAR & SEM & $P$-value \\
\hline pH & 6.22 & 6.19 & 6.19 & 6.19 & 0.027 & 0.88 \\
Total VFA $(\mathrm{m} M)$ & 140.2 & 141.1 & 143.9 & 142.4 & 2.59 & 0.76 \\
VFA (mol/100 mol) & 62.1 & 60.5 & 61.7 & 61.7 & 0.54 & 0.25 \\
Acetate & $20.8^{\mathrm{b}}$ & $22.6^{\mathrm{a}} \dagger$ & $21.1^{\mathrm{ab}} \dagger$ & $21.0^{\mathrm{ab}_{\dagger} \dagger}$ & 0.43 & 0.03 \\
Propionate & 12.5 & 12.2 & 12.5 & 12.7 & 0.30 & 0.75 \\
Butyrate & 2.57 & 2.69 & 2.49 & 2.58 & 0.062 & 0.19 \\
Branched-chain VFA & 1.49 & 1.46 & 1.53 & 1.47 & 0.039 & 0.59 \\
Valerate & 0.64 & 0.54 & 0.65 & 0.59 & 0.034 & 0.11 \\
Caproate & $3.03^{\mathrm{a}}$ & $2.71^{\mathrm{b}}$ & $2.95^{\mathrm{ab}}$ & $2.98^{\mathrm{ab}}$ & 0.081 & 0.05 \\
Acetate:propionate & 8.17 & 7.30 & 7.60 & 7.78 & 0.409 & 0.52 \\
Ammonia $(\mathrm{m} M)$ & 8.44 & 6.49 & 8.09 & 7.42 & 0.779 & 0.33 \\
Protozoa $\left(\log _{10} / \mathrm{mL}\right)$ & & & & & & \\
\hline
\end{tabular}

${ }_{\mathrm{a}, \mathrm{b}}$ Means within a row with different superscripts differ $(P<0.05)$.

${ }^{1}$ Sum of isobutyrate and isovalerate.

$\dagger P=0.10$ : MON vs. ORE; $P=0.09$ : MON vs. CAR. 


\section{Enteric $\mathrm{CH}_{4}$ Production}

Data on the effect of the feed additives on enteric $\mathrm{CH}_{4}$ production are presented in Table 4. Compared with CTL, diet supplementation with MON, ORE, or CAR did not affect enteric $\mathrm{CH}_{4}$ production expressed in grams/day $(491 \mathrm{~g} / \mathrm{d}$, on average) or on a DMI basis $(21.1 \mathrm{~g} / \mathrm{d}$, on average). When expressed as a proportion of $\mathrm{GE}$ intake, $\mathrm{CH}_{4}$ energy losses were similar for cows fed CTL, MON, ORE, and CAR (6.14\% of GE intake, on average).

\section{Milk Production and Milk Composition}

Milk performance data are shown in Table 5. Milk production was not altered by the inclusion of MON, ORE, or CAR in the diet $(34.2 \mathrm{~kg} / \mathrm{d}$, on average). Likewise, milk concentrations of fat $(3.75 \%)$, lactose (4.61\%), and MUN (10.5 mg/L) were similar among cows. For milk yield components, protein yield was lower $(P=0.05)$ for cows fed CAR compared with cows fed ORE (1.08 vs. $1.13 \mathrm{~kg} / \mathrm{d})$. None of the feed additives affected feed efficiency, which averaged $1.43 \mathrm{~kg}$ of milk/kg of DMI.

\section{Milk Fatty Composition}

Data on the effects on milk fatty composition (g/100 g) are shown in Table 6. Concentrations of $6: 0$ and 8:0 tended ( $P=0.08$ and 0.07 , respectively) to be lower in milk fat of cows fed MON than in those fed CTL (1.864 vs. 1.963 and 1.048 vs. $1.130 \mathrm{~g} / 100 \mathrm{~g}$, respectively). In contrast, the concentration of 17:0 was higher $(P$ $<0.05)$ in milk fat of cows fed MON than in cows fed CTL (0.515 vs. $0.477 \mathrm{~g} / 100 \mathrm{~g})$. Concentrations of trans-9 18:1 and trans-10 18:1 were higher $(P<0.01)$ for cows fed MON (0.179 and $0.322 \mathrm{~g} / 100 \mathrm{~g}$, respectively) compared with cows fed CTL, ORE, or CAR (0.167 and $0.263 \mathrm{~g} / 100 \mathrm{~g}$ for trans-9 18:1 and trans-10 $18: 1$, on average, respectively). The concentration of trans-11 18:1 was lower for cows fed MON than for cows fed ORE (0.707 vs. $0.793 \mathrm{~g} / 100 \mathrm{~g}$ of fat; $P<$ $0.05)$. The concentration of this FA tended $(P=0.10)$ to decrease when cows were fed CAR compared with ORE $(0.718$ vs. $0.793 \mathrm{~g} / 100 \mathrm{~g})$. The concentration of trans-12 18:1 was higher $(P<0.05)$ for cows fed MON than for cows fed CTL or CAR (0.397 vs. 0.359 and $0.347 \mathrm{~g} / 100 \mathrm{~g})$. Cows fed MON tended $(P=0.11)$ to have a higher concentration of trans-12 18:1 than cows fed ORE (0.397 vs. $0.366 \mathrm{~g} / 100 \mathrm{~g})$. Cows fed MON had higher $(P<0.01)$ concentrations of trans-15 18:1 and trans-16 18:1 (0.409 and 0.336 g/100 g, respectively) than cows fed CTL, ORE, and CAR (0.363 and 0.290 $\mathrm{g} / 100 \mathrm{~g}$ for trans-15 18:1 and trans-16 18:1, on average, respectively). The concentration of cis-9,trans-11 18:2 decreased $(P<0.01)$ when cows were fed CAR compared with ORE (0.304 vs. $0.354 \mathrm{~g} / 100 \mathrm{~g})$. Cows fed MON had a higher concentration of trans-8, cis-13 18:2 compared with cows fed CTL, ORE, and CAR (0.081 vs. $0.66 \mathrm{~g} / 100 \mathrm{~g})$. Cows fed MON had higher $(P<0.05)$ concentrations of trans-9,cis-13 + trans-8,cis-12 18:2 compared with cows fed ORE or CAR (0.286 vs. 0.256 and $0.243 \mathrm{~g} / 100 \mathrm{~g}$, respectively). The concentration of trans-9,cis-13 + trans-8,cis-12 18:2 tended $(P=0.08)$ to increase in milk fat of cows fed MON versus those fed CTL (0.286 vs. $0.258 \mathrm{~g} / 100 \mathrm{~g}$ ). The ratio of trans-11 18:1 to trans-10 18:1 was lower $(P<0.05)$ for cows fed MON than for cows fed CTL, ORE, and CAR (2.241 vs. 2.875 , respectively).

\section{DISCUSSION}

This study was undertaken to examine the potential of using oregano oil and its main component carvacrol as feed additives in dairy cow nutrition. Little information is available on the use of oregano oil in dairy cow diets and, to our knowledge, no studies have been published on the effects of pure carvacrol on ruminal fermentation, $\mathrm{N}$ excretion, enteric $\mathrm{CH}_{4}$ production, and milk performance of dairy cows.

Table 4. Enteric $\mathrm{CH}_{4}$ production in lactating cows fed a TMR without supplementation (control, CTL), or supplemented with monensin (MON), oregano oil (ORE), or carvacrol (CAR)

\begin{tabular}{|c|c|c|c|c|c|c|}
\hline \multirow[b]{2}{*}{ Item } & \multicolumn{4}{|c|}{ Treatment } & \multirow[b]{2}{*}{ SEM } & \multirow[b]{2}{*}{$P$-value } \\
\hline & CTL & MON & ORE & CAR & & \\
\hline $\mathrm{DMI}^{1}(\mathrm{~kg} / \mathrm{d})$ & 23.4 & 22.6 & 23.8 & 23.2 & 0.46 & 0.23 \\
\hline $\begin{array}{l}\mathrm{CH}_{4} \\
\mathrm{~g} / \mathrm{d}\end{array}$ & 488 & 462 & 511 & 502 & 16.6 & 0.14 \\
\hline $\mathrm{g} / \mathrm{kg}$ of $\mathrm{DMI}$ & $\begin{array}{r}400 \\
20.9\end{array}$ & 20.3 & 21.5 & 21.6 & $\begin{array}{r}10.0 \\
0.49\end{array}$ & 0.17 \\
\hline$\%$ of GE intake & 6.02 & 5.89 & 6.33 & 6.34 & 0.153 & 0.08 \\
\hline
\end{tabular}

${ }^{1}$ Measured during enteric methane determination period (i.e., $7 \mathrm{~d}$, each period). 
Table 5. Milk production and milk composition of lactating cows fed a TMR without supplementation (control, CTL) or supplemented with monensin (MON), oregano oil (ORE), or carvacrol (CAR)

\begin{tabular}{lcccccc}
\hline & \multicolumn{7}{c}{ Treatment } & & \\
\cline { 2 - 4 } Item & CTL & MON & ORE & CAR & SEM & $P$-value \\
\hline Production (kg/d) & 34.3 & 34.2 & 34.6 & 33.6 & 0.46 & 0.53 \\
Composition (\%) & 3.71 & 3.76 & 3.79 & 3.73 & 0.083 & 0.92 \\
$\quad$ Fat & 3.30 & 3.27 & 3.30 & 3.23 & 0.024 & 0.13 \\
Protein & 4.62 & 4.60 & 4.62 & 4.62 & 0.020 & 0.84 \\
Lactose & & & & & & \\
Yield (kg/d) & 1.27 & 1.29 & 1.32 & 1.27 & 0.023 & 0.41 \\
Fat & $1.12^{\text {ab }}$ & $1.11^{\text {ab }}$ & $1.13^{\mathrm{a}}$ & $1.08^{\mathrm{b}}$ & 0.014 & 0.06 \\
Protein & 1.59 & 1.58 & 1.61 & 1.56 & 0.024 & 0.59 \\
Lactose & 10.6 & 10.7 & 10.4 & 10.4 & 0.36 & 0.94 \\
MUN (mg/dL) & 1.44 & 1.46 & 1.41 & 1.42 & 0.021 & 0.43 \\
Feed efficiency (milk/DMI) & & & & & & \\
\hline
\end{tabular}

${ }^{\mathrm{a}, \mathrm{b}}$ Means within a row with different superscripts differ $(P<0.05)$.

\section{Effect on DMI, Total-Tract Apparent Digestibility, and $\mathrm{N}$ Excretion}

Diet supplementation with ORE did not affect DMI or total-tract apparent digestibility of nutrients. Kolling et al. (2018) observed no change in DMI (measured outside the chambers) or digestibility of DM, fiber, $\mathrm{CP}$, and GE in cows fed oregano extract $(10 \mathrm{~g} / \mathrm{d}$; $0.056 \%$ of dietary DM; $5 \%$ EO, $80 \%$ carvacrol). When feeding dairy cows large amounts of dried oregano leaves (250 to $750 \mathrm{~g} / \mathrm{d}$ ), Hristov et al. (2013) observed a linear decrease in DMI. In Hristov et al. (2013), the concentration of EO in oregano leaves was $1.58 \%$ of DM, which means that cows were supplemented daily with 4 to $12 \mathrm{~g} / \mathrm{d}$ of EO, corresponding to 140 to 445 $\mathrm{mg} / \mathrm{kg}$ of dietary DM. This level of supplementation is 3 to 9 times higher than that used in the current study (50 mg $/ \mathrm{kg}$ of DMI), which may explain the discrepancy between the 2 studies. Nitrogen excretion (i.e., urinary $\mathrm{N}$, fecal $\mathrm{N}$, and total) was unaffected by ORE supplementation, which is in accordance with findings by Hristov et al. (2013) in lactating cows supplemented with oregano leaves $(250$ to $750 \mathrm{~g} / \mathrm{d}$ ). In the present study, adding CAR to the diet had no effect on DMI and total-tract apparent digestibility of nutrients and $\mathrm{N}$ excretion. Information on feeding CAR to dairy cows is available. In one study with lambs, Chaves et al. (2008) observed no change in DMI when the animals were supplemented with $200 \mathrm{mg} / \mathrm{kg}$ of dietary DM of carvacrol.

The ionophore monensin has been extensively investigated in dairy cows. In the present study, feeding MON (24 mg/kg of DM) did not affect DMI, which agrees with the results of other studies with dairy cows fed MON at a feeding rate similar to that used in the current study (Grainger et al., 2010; Benchaar, 2016). Total-tract apparent digestibility of DM, OM, NDF, and GE was unaffected by MON supplementation. Supplementing the diet with MON tended $(P=0.10)$ to increase CP digestibility, which is in agreement with previous studies with dairy cattle fed MON (Plaizier et al., 2000; Benchaar et al., 2006). In contrast, Plaizier et al. (2000) and Benchaar (2016) reported no effect of MON on CP digestibility in dairy cows. Differences between studies in $\mathrm{CP}$ digestibility response to $\mathrm{MON}$ may be due to diet composition (i.e., forage:concentrate ratio) or the dose of MON used (Benchaar et al., 2006; Benchaar, 2016).

\section{Effect on Rumen Fermentation and Protozoa}

Ruminal $\mathrm{pH}$ and VFA (total and individual) proportions were unaffected by feeding cows ORE and CAR. Feeding oregano leaves (500 g/d; Tekippe et al., 2011) or extract (10 g/d; Kolling et al., 2018) did not change ruminal $\mathrm{pH}$ and total VFA concentration. In our study and these previous studies, the lack of effect on ruminal $\mathrm{pH}$ and total VFA concentration was consistent with the absence of effects of the additives on DMI, rumen digestion, and total-tract apparent digestibility of nutrients. Ruminal ammonia concentration and protozoa number were not affected by the addition of ORE and CAR, which is in agreement with the lack of change in branched-chain VFA (i.e., sum of isobutyrate and isovalerate) molar proportion. Other studies also reported no effect of diet supplementation with leaves or extract on ruminal ammonia concentration (Hristov et al., 2013; Kolling et al., 2018). In contrast, Tekippe et al. (2011) observed a significant increase in ruminal ammonia concentration, a finding that contradicts the reported antimicrobial properties of oregano oil and carvacrol. Oregano oil and carvacrol have been shown to decrease protein degradation and ammonia concentration in vitro (Busquet et al., 2005; Macheboeuf et al., 
Table 6. Milk fat composition (g/100 g) of lactating cows fed a TMR without supplementation (control, CTL), or supplemented with monensin (MON), oregano oil (ORE), or carvacrol (CAR)

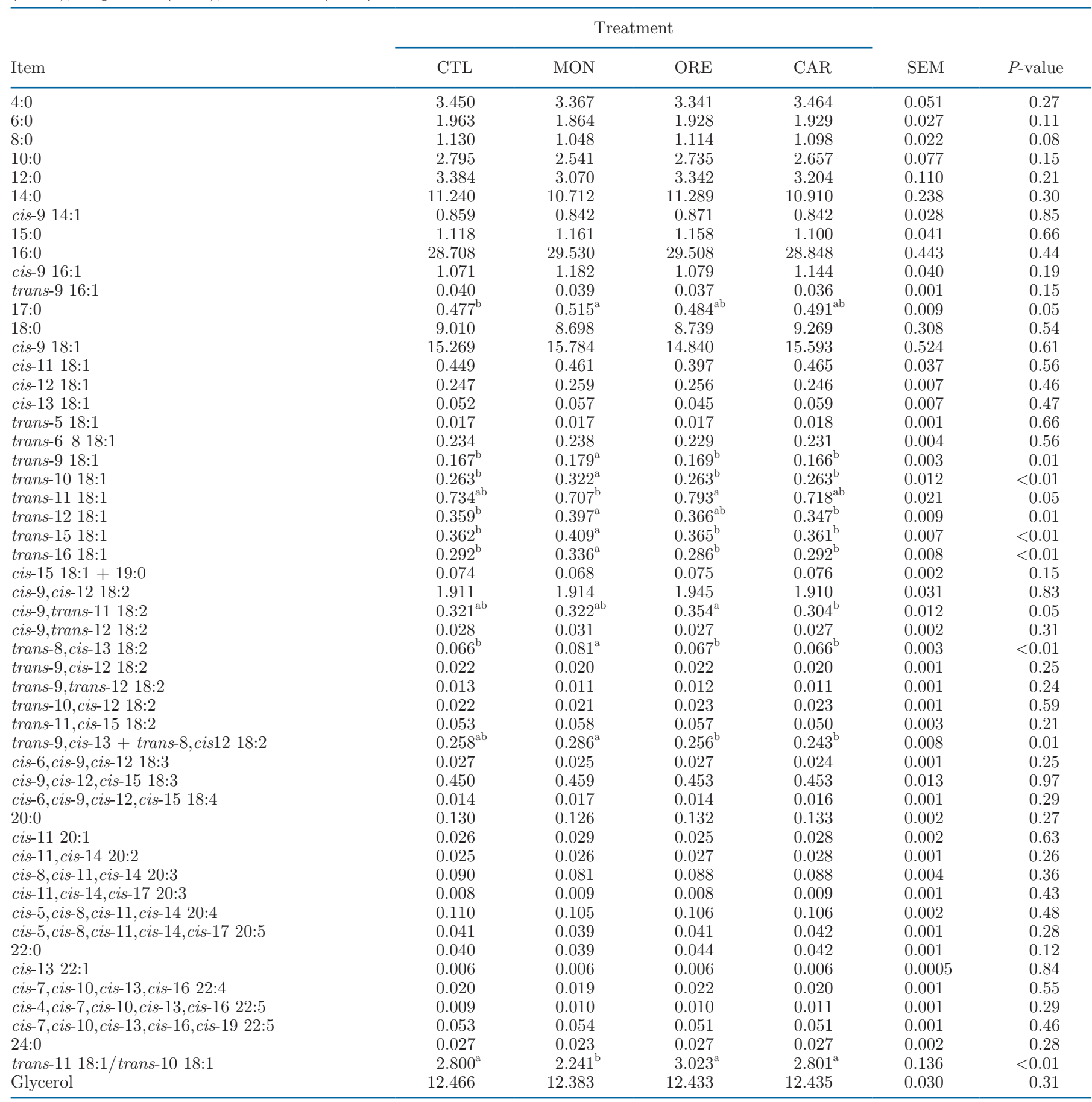

${ }^{\mathrm{a}, \mathrm{b}}$ Means within a row with different superscripts differ $(P<0.05)$.

2008). The lack of effects of ORE and CAR on ruminal protozoa is in agreement with findings by Tekippe et al. (2011) and Hristov et al. (2013).

The only noticeable change in ruminal fermentation characteristics when MON was added to the diet was the increase in propionate molar proportion and, con- sequently, a decrease in the acetate-to-propionate ratio. Monensin is known to shift rumen fermentation toward propionate production (Beauchemin et al., 2009; Martin et al., 2010). However, the effect of this ionophore on VFA pattern was inconsistent among studies and this discrepancy is more likely due to the dose, the 
forage:concentrate ratio of the diet, or the source of starch, as discussed by Benchaar (2016).

\section{Effect on Enteric Methane}

Dry matter intake determined during the $\mathrm{CH}_{4}$ measurement period (i.e., $7 \mathrm{~d}$ ) averaged $23.2 \mathrm{~kg} / \mathrm{d}$ (Table 4), which is close to average DMI $(23.7 \mathrm{~kg} / \mathrm{d}$; on average) measured during the digestibility period (i.e., 7 d). Methane production averaged $491 \mathrm{~g} / \mathrm{d}, 21.1 \mathrm{~g} / \mathrm{kg}$ of DMI, and $6.14 \%$ of GE intake. These emissions are close to the emissions observed in our previous studies using respiration chambers for cows with similar levels of DMI (Benchaar et al., 2013; Hassanat et al., 2014).

Several in vitro studies have evaluated the antimethanogenic properties of oregano oil and carvacrol (see review by Benchaar and Greathead, 2011). However, information on the effect of oregano oil on enteric $\mathrm{CH}_{4}$ production in dairy cows (i.e., in vivo) is very scarce and such information is not available for carvacrol. Using respiration chambers, Lejonklev et al. (2016) reported no effect on enteric $\mathrm{CH}_{4}$ emission (L/d, L/ kg DMI, or $\%$ of GE intake) in dairy cows fed oregano oil at 0.2 and $1.0 \mathrm{~g} / \mathrm{kg}$ of DM (i.e., 4.3 and $22.4 \mathrm{~g} / \mathrm{d}$ ), which agrees with results presented in the current study. Kolling et al. (2018) evaluated the effects of oregano extract $(0.056 \%$ of dietary DM) on enteric $\mathrm{CH}_{4}$ production from dairy cows using respiration chambers. The authors reported no effect of the oregano extract on daily $\mathrm{CH}_{4}$ emission (318 and $320 \mathrm{~g} / \mathrm{d}$, for the control and oregano extract treatments, respectively). When expressed on a DMI basis, $\mathrm{CH}_{4}$ production tended $(P=0.06)$ to decrease in cows fed oregano extract compared with cows fed the control diet (15.3 vs. $19.7 \mathrm{~g} / \mathrm{kg}$ of DMI). This decrease in $\mathrm{CH}_{4}(\mathrm{~g} / \mathrm{kg}$ of DMI) was mainly due to an increase in DMI measured in the chambers, for cows fed the oregano supplement compared with cows fed the control diet (20.6 vs. $16.3 \mathrm{~kg} / \mathrm{d} ; P=0.08)$. It is worth noting that DMI measured outside of the chambers was unaffected by oregano extract. The decline in $\mathrm{CH}_{4}$ yield (g/kg of DMI) observed by Kolling et al. (2018) was not supported by the lack of effects on rumen fermentation (i.e., $\mathrm{pH}$, total VFA and acetate:propionate ratio) and nutrient (i.e., TDN) digestibility data. Therefore, it is possible that the reduction in $\mathrm{CH}_{4}$ production was due to the increased DMI $(+4 \mathrm{~kg} / \mathrm{d})$, which may have increased the ruminal passage rate. Previous studies (Okine et al., 1989; Hammond et al., 2014) showed that a faster ruminal passage rate is generally associated with a reduction in enteric $\mathrm{CH}_{4}$ production $(\mathrm{g} / \mathrm{kg}$ of DMI or \% GE intake). More recently, Olijhoek et al. (2019) observed no change in enteric $\mathrm{CH}_{4}$ production (g/d, g/kg of DMI, \% of GE intake) in cows fed increasing amounts of dried whole-plant oregano with either low ( $0.12 \%$ EO; $31 \%$ carvacrol; $23 \%$ thymol) or high (4.21\% EO; $35 \%$ carvacrol; $41 \%$ thymol) levels of EO compared with cows fed the control diet. The absence of effect on $\mathrm{CH}_{4}$ production in their study was consistent with the lack of changes in DMI, OM digestion (ruminal and total-tract), and rumen fermentation characteristics (i.e., acetate-to-propionate ratio).

Tekippe et al. (2011) and Hristov et al. (2013) evaluated the effect of including oregano leaves in dairy cow diets on $\mathrm{CH}_{4}$ production using the $\mathrm{SF}_{6}$ tracer technique and collecting gas samples from the rumen headspace at 2, 4, 6, and $8 \mathrm{~h}$ after feeding, during $1 \mathrm{~d}$. In Tekippe et al. (2011), the oregano leaves supplement was introduced into the rumen as a pulse dose at the time of feeding. In that study, diet supplementation with 500 $\mathrm{g}$ of oregano leaves $(7 \mathrm{~g} / \mathrm{d}$ of EO; $6.9 \mathrm{~g} / \mathrm{d}$ of carvacrol) decreased $\mathrm{CH}_{4}$ production by $40 \%$ (expressed as $\mathrm{g} / \mathrm{h}$ ) but had no effect on DMI. In Hristov et al. (2013), dietary addition of oregano leaves $(250,500$, and 700 $\mathrm{g} / \mathrm{d} ; 4.0,7.9$, and $11.9 \mathrm{~g} / \mathrm{d}$ of EO; 3,6 , and $9 \mathrm{~g} / \mathrm{d}$ of carvacrol, respectively), tended to decrease $(P=0.06)$ and increased linearly $(P=0.05) \mathrm{CH}_{4}$ production when expressed in grams per day and grams per kilogram of DMI, respectively. The greater decrease was observed with the medium level (i.e., $500 \mathrm{~g} / \mathrm{d}$ ) of oregano leaves inclusion (36 vs. $26 \%$ decrease) but not with the highest level (i.e., $750 \mathrm{~g} / \mathrm{d}$ ). It is possible that the inhibitory effect observed by Hristov et al. (2013) was due to the decrease in DMI when cows were supplemented with oregano leaves. In both studies, the decrease in $\mathrm{CH}_{4}$ production was not consistent with the lack of effect on DMI (Tekippe et al., 2011), ruminal fermentation characteristics ( $\mathrm{pH}$, total VFA, and the acetate:propionate ratio), protozoa number, and Methanobrevibacter, the predominant methanogen in the rumen (Tekippe et al., 2011; Hristov et al., 2013). Several factors can explain this inconsistency. First, the validity of collecting gas samples from the rumen headspace versus breath samples. Second, the short duration of $\mathrm{CH}_{4}$ measurement period ( $1 \mathrm{~d}$; within $8 \mathrm{~h}$ after feeding), which makes uncertain that the effect of oregano leaves would have persisted over an entire $24 \mathrm{~h}$. Benchaar et al. (2009) and Benchaar and Greathead (2011) reported the ability of rumen microbes to adapt to EO, degrade EO, or both. Third, in Tekippe et al. (2011), the oregano leaves were pulse-dosed into the rumen at the time of feeding, thus inducing a greater effect on $\mathrm{CH}_{4}$ production during $\mathrm{CH}_{4}$ measurement within $8 \mathrm{~h}$ of feeding. Because of these limitations in the method used by Tekippe et al. (2011) and Hristov et al. (2013) to quantify $\mathrm{CH}_{4}$ emissions, the authors warned that $\mathrm{CH}_{4}$ data from their studies must be interpreted with caution. Finally, as indicated by Tekippe et al. (2011), the concentrations of EO provided by $500 \mathrm{~g} / \mathrm{d}$ of oregano leaves (i.e., $7.5 \mathrm{~g} / \mathrm{d}$ of EO; 
$6.6 \mathrm{~g} / \mathrm{d}$ of carvacrol) in their study are too high to feed to dairy cows under practical feeding conditions.

In the current study, compared with CTL, MON had no effect on $\mathrm{CH}_{4}$ production. This result is consistent with the lack of MON effect on intake, ruminal digestion, and protozoa, but not with the lower acetate: propionate ratio. Reasons for this discrepancy are unclear because one of the mechanisms by which MON inhibits $\mathrm{CH}_{4}$ production is by shifting rumen fermentation toward propionogenesis (Beauchemin et al., 2009; Martin et al., 2010).

\section{Effect on Milk Production and Milk Composition}

Supplementation of MON, ORE, and CAR did not affect milk production and milk composition. In agreement with Kolling et al. (2018), milk yield and milk composition were unaffected by feeding oregano extract to dairy cows $(10 \mathrm{~g} / \mathrm{d} ; 0.0156 \%$ of dietary $\mathrm{DM})$, results that were consistent with the absence of effects on DMI and ruminal fermentation characteristics in that study. Likewise, Hristov et al. (2013) reported no changes in milk yield and milk components in dairy cows fed increasing amount of oregano leaves (up to $750 \mathrm{~g} / \mathrm{d} ; 12$ $\mathrm{g} / \mathrm{d} \mathrm{EO} ; 9 \mathrm{~g} / \mathrm{d}$ carvacrol). The lack of effect on milk yield was associated with a linear decrease in DMI. In a previous study by the same group (Tekippe et al., 2011), adding $500 \mathrm{~g} / \mathrm{d}$ of oregano leaves (i.e., 7.0 $\mathrm{g} / \mathrm{d}$ EO; $6.9 \mathrm{~g} / \mathrm{d}$ carvacrol), did not affect milk yield and milk protein content but increased concentration and yield of milk fat. In Tekippe et al. (2011), DMI and the VFA profile (particularly the molar proportion of acetate) were not affected by oregano leaves supplementation, which does not explain the observed change in milk fat. Adding MON to the diet had no effect on milk yield and milk components, which agrees with other studies with cows fed MON at similar dose as used in our study (Grainger et al., 2010; do Prado et al., 2015; Benchaar, 2016).

\section{Effect on Milk FA Composition}

Little information is available on the effect of feeding oregano oil and carvacrol on milk FA profile. In the current study, no change in milk FA was observed when cows were fed ORE and CAR versus CTL. Likewise, other studies reported no or only minor effects on milk FA in dairy cows fed oregano leaves or extract (Hristov et al., 2013; Kolling et al., 2018). Benchaar (2016) reported no change in milk FA profile of cows fed the phenolic compound eugenol (50 mg/kg of dietary DM).

In the present study, feeding MON to cows affected the proportions of some FA in milk fat. One particular change of interest was the increase in the trans-10 18:1 proportion, whereas the trans-11 18:1 proportion was not changed. Consequently, the trans-11:trans-10 ratio was also decreased by MON supplementation. Using a continuous culture system of ruminal bacteria, Jenkins et al. (2003) observed that supplying monensin at 25 ppm increased the concentration of trans-10 18:1 but not that of trans-11 18:1. Increased milk fat concentration of trans-10 18:1 has been related to an inhibition of milk fat synthesis (Griinari et al., 1998). Benchaar et al. (2006) observed a higher concentration of trans-10 18:1 associated with lower milk fat content in cows fed MON. In the current study, such an increase in trans-10 18:1 was apparently not enough to induce inhibition of milk fat synthesis.

\section{CONCLUSIONS}

Results from this study do not confirm the antimicrobial activities of oregano oil and its main component, the phenolic carvacrol, as reported in several short-term in vitro studies. Under the conditions of this study, diet supplementation with $\mathrm{ORE}$ and CAR at $50 \mathrm{mg} / \mathrm{kg}$ of dietary DM did not affect nutrient utilization, ruminal fermentation characteristics, $\mathrm{N}$ excretion, $\mathrm{CH}_{4}$ production, production, milk production, milk composition, or milk FA profile. The findings of enteric $\mathrm{CH}_{4}$ production contrast with the limited in vivo data in the literature on feeding oregano plant, leaves, or extract to dairy cows. When supplied at $50 \mathrm{mg} / \mathrm{kg}$ of $\mathrm{DM}$, oregano oil and carvacrol are likely not a viable strategy to improve feed efficiency, decrease $\mathrm{N}$ excretion, mitigate enteric methane, or enhance milk performance in dairy cows.

\section{ACKNOWLEDGMENTS}

The author is grateful to L. Croteau (for technical assistance), S. Méthot (for help with statistical analyses), and the staff of the dairy facility (for care of the animals) from the Sherbrooke Research and Development Centre (Agriculture and Agri-Food Canada, Sherbrooke, QC, Canada). The author also thanks P. Y. Chouinard (Département des Sciences Animales, Université Laval, Quebec, QC, Canada) for milk FA analysis. Finally, the author is grateful to Phodé (Albi, France) for the provision of oregano oil and carvacrol. Financial support for the study was from Agriculture and Agri-Food Canada (Ottawa, ON, Canada).

\section{REFERENCES}

AOAC International. 2005. Official Methods of Analysis. 18th ed. AOAC International, Arlington, VA.

Baričevič, D., and T. Bartol. 2002. The biological/pharmacological activity of the Origanum genus. Pages 177-213 in Oregano: The 
Genera Origanum and Lippia. S. E. Kintzios, ed. Taylor and Francis, London, UK.

Beauchemin, K., T. A. McAllister, and S. M. McGinn. 2009. Dietary mitigation of enteric methane from cattle. CAB Reviews: Perspect. Agric. Vet. Sci. Nutr. Nat. Resour. 4:1-18. https://doi.org/ 10.1079/PAVSNNR20094035.

Benchaar, C. 2016. Diet supplementation with cinnamon oil, cinnamaldehyde, or monensin does not reduce enteric methane production of dairy cows. Animal 10:418-425. https://doi.org/10.1017/ S175173111500230X.

Benchaar, C., S. Calsamiglia, A. V. Chaves, G. R. Fraser, D. Colombatto, T. A. McAllister, and K. A. Beauchemin. 2008. A review of plant-derived essential oils in ruminant nutrition and production. Anim. Feed Sci. Technol. 145:209-228. https://doi.org/10.1016/j anifeedsci.2007.04.014

Benchaar, C., and H. Greathead. 2011. Essential oils and opportunities to mitigate enteric methane emissions from ruminants. Anim. Feed Sci. Technol. 166-167:338-355. https://doi.org/10.1016/j .anifeedsci.2011.04.024.

Benchaar, C., F. Hassanat, R. Gervais, P. Y. Chouinard, C. Julien, H. V. Petit, and D. I. Massé. 2013. Effects of increasing amounts of corn dried distillers grains with solubles in dairy cow diets on methane production, ruminal fermentation, digestion, $\mathrm{N}$ balance, and milk production. J. Dairy Sci. 96:2413-2427. https://doi.org/ 10.3168/jds.2012-6037.

Benchaar, C., A. N. Hristov, and H. Greathead. 2009. Essential oils as feed additives in animal nutrition. Pages 111-146 in Phytogenics in Animal Nutrition. T. Steiner, ed. Nottingham University Press, Nottingham, UK.

Benchaar, C., H. V. Petit, R. Berthiaume, T. D. Whyte, and P. Y. Chouinard. 2006. Effects of addition of essential oils and monensin premix on digestion, ruminal fermentation, milk production, and milk composition in dairy cows. J. Dairy Sci. 89:4352-4364. https: //doi.org/10.3168/jds.S0022-0302(06)72482-1.

Busquet, M., S. Calsamiglia, A. Ferret, and C. Kamel. 2005. Screening for effects of plant extracts and active compounds of plants on dairy cattle rumen microbial fermentation in a continuous culture system. Anim. Feed Sci. Technol. 123/124:597-613. https://doi .org/10.1016/j.anifeedsci.2005.03.008.

Calsamiglia, S., M. Busquet, P. W. Cardozo, L. Castillejos, and A. Ferret. 2007. Invited review: Essential oils as modifiers of rumen microbial fermentation. J. Dairy Sci. 90:2580-2595. https://doi .org/10.3168/jds.2006-644.

Canadian Council on Animal Care. 2009. CCAC Guidelines on the Care and Use of Farm Animals in Research, Teaching and Testing. Canadian Council on Animal Care, Ottawa, ON, Canada.

Chaves, A. V., K. Stanford, L. Gibson, T. A. McAllister, and C. Benchaar. 2008. Effects of carvacrol and cinnamaldehyde on intake, rumen fermentation, growth performance, and carcass characteristics of growing lambs. Anim. Feed Sci. Technol. 145:396408. https://doi.org/10.1016/j.anifeedsci.2007.04.016.

Chouinard, P. Y., J. Lévesque, V. Girard, and G. J. Brisson. 1997. Dietary soybeans extruded at different temperatures. Milk composition and in situ fatty acid reactions. J. Dairy Sci. 80:2913-2924. https://doi.org/10.3168/jds.S0022-0302(97)76257-X.

Cobellis, G., M. Trabalza-Marinucci, and Z. Yu. 2016. Critical evaluation of essential oils as rumen modifiers in ruminant nutrition: A review. Sci. Total Environ. 545-546:556-568. https://doi.org/10 $.1016 /$ j.scitotenv.2015.12.103.

Cochran, W. G., and G. M. Cox. 1957. Experimental Designs. 2nd ed. John Wiley \& Sons Inc., New York, NY.

Cushnie, T. P. T., and A. J. Lamb. 2005. Antimicrobial activity of flavonoids. Int. J. Antimicrob. Agents 26:343-356. https://doi.org/10 .1016/j.ijantimicag.2005.09.002.

do Prado, R. M., C. Côrtes, C. Benchaar, and H. V. Petit. 2015. Interaction of sunflower oil with monensin on milk composition, milk fatty acid profile, digestion, and ruminal fermentation in dairy cows. Anim. Feed Sci. Technol. 207:85-92. https://doi.org/ 10.1016/j.anifeedsci.2015.06.017.
European Union. 2003. Regulation (EC) No 1831/2003 of the European Parliament and the Council of 22 September 2003 on additives for use in animal nutrition. Off. J. L268/36.

Farnworth, E. R., P. Y. Chouinard, H. Jacques, S. Venkatramanan, A Maf, S. Defnoun, and P. Jones. 2007. The effect of drinking milk containing conjugated linoleic acid on fecal microbiological profile, enzymatic activity, and fecal characteristics in humans. Nutr. J. 6:15. https://doi.org/10.1186/1475-2891-6-15.

Grainger, C., R. Williams, R. J. Eckard, and M. C. Hannah. 2010. A high dose of monensin does not reduce methane emissions of dairy cows offered pasture supplemented with grain. J. Dairy Sci. 93:5300-5308. https://doi.org/10.3168/jds.2010-3154.

Griinari, J. M., D. A. Dwyer, M. A. McGuire, D. E. Bauman, D. L. Palmquist, and K. V. V. Nurmela. 1998. Trans-octadecenoic acids and milk fat depression in lactating dairy cows. J. Dairy Sci. 81:1251-1261. https://doi.org/10.3168/jds.S0022-0302(98)75686 $-3$.

Hammond, K. J., D. Pacheco, J. L. Burke, J. P. Koolaard, S. Muetzel, and G. C. Waghorn. 2014. The effects of fresh forages and feed intake level on digesta kinetics and enteric methane emissions from sheep. Anim. Feed Sci. Technol. 193:32-43. https://doi.org/ 10.1016/j.anifeedsci.2014.04.005.

Hassanat, F., R. Gervais, D. I. Massé, H. V. Petit, and C. Benchaar. 2014. Methane production, nutrient digestion, ruminal fermentation, nitrogen balance, and milk production of cows fed timothy silage- or alfalfa silage-based diets. J. Dairy Sci. 97:6463-6474. https://doi.org/10.3168/jds.2014-8069.

Hristov, A. N., C. Lee, T. Cassidy, K. Heyler, J. A. Tekippe, G. A. Varga, B. Corl, and R. C. Brandt. 2013. Effect of Origanum vulgare L. leaves on rumen fermentation, production, and milk fatty acid composition in lactating dairy cows. J. Dairy Sci. 96:1189-1202. https://doi.org/10.3168/jds.2012-5975.

Jenkins, T. C., V. Fellner, and R. K. McGuffey. 2003. Monensin by fat interactions on trans fatty acids in cultures of mixed ruminal microorganisms grown in continuous fermentors fed corn or barley. J. Dairy Sci. 86:324-330. https://doi.org/10.3168/jds.S0022 -0302(03)73609-1.

Johnson, K., M. Huyler, H. Westberg, B. Lamb, and P. Zimmerman. 1994. Measurement of methane emissions from ruminant livestock using a sulfur hexafluoride tracer technique. Environ. Sci. Technol. 28:359-362. https://doi.org/10.1021/es00051a025.

Kerala, K. V. 2001. Handbook of Herbs and Spices. K. V. Kerala, ed. Woodhead Publishing Ltd., Cambridge, UK.

Kolling, G. J., S. C. B. Stivanin, A. M. Gabbi, F. S. Machado, A. L. Ferreira, M. M. Campos, T. R. Tomich, C. S. Cunha, S. W. Dill, L. G. R. Pereira, and V. Fischer. 2018. Performance and methane emissions in dairy cows fed oregano and green tea extracts as feed additives. J. Dairy Sci. 101:4221-4234. https://doi.org/10.3168/ jds.2017-13841.

Lejonklev, J., U. Kidmose, S. Jensen, M. Petersen, A. L. F. Helwing, G. Mortensen, M. R. Weisbjerg, and M. Larsen. 2016. Short communication: Effect of oregano and caraway essential oils on the production and flavor of cow's milk. J. Dairy Sci. 99:7898-7903. https://doi.org/10.3168/jds.2016-10910.

Macheboeuf, D., D. P. Morgavi, Y. Papon, J. L. Mousset, and M. Arturo-Schaan. 2008. Dose-response effects of essential oils on in vitro fermentation activity of the rumen microbial population. Anim. Feed Sci. Technol. 145:335-350. https://doi.org/10.1016/j .anifeedsci.2007.05.044.

Martin, C., D. P. Morgavi, and M. Doreau. 2010. Methane mitigation in ruminants: From microbe to the farm scale. Animal 4:351-365. https://doi.org/10.1017/S1751731109990620.

McGinn, S. M., K. A. Beauchemin, A. D. Iwaasa, and T. A. McAllister. 2006. Assessment of the sulfur hexafluoride (SF6) tracer technique for measuring enteric methane emissions from cattle. J. Environ. Qual. 35:1686-1691. https://doi.org/10.2134/jeq2006 .0054 .

NRC. 2001. Nutrient Requirements of Dairy Cattle. 7th rev. ed. Natl. Acad. Press, Washington, DC. https://doi.org/10.17226/9825. 
Ogimoto, K., and S. Imai. 1981. Techniques of rumen microbiology. Page 158 in Atlas of Rumen Microbiology. Japan Sci. Soc. Press, Tokyo, Japan.

Okine, E. K., G. W. Mathison, and R. T. Hardin. 1989. Effects of changes in frequency of reticular contractions on fluid and particulate passage rates in cattle. J. Anim. Sci. 67:3388-3396. https:// doi.org/10.2527/jas1989.67123388x.

Olijhoek, D. W., A. L. F. Hellwing, K. Grevsen, L. S. Haveman, M. R. Chowdhury, P. Løvendahl, M. R. Weisbjerg, S. J. Noel, O. Højberg, L. Wiking, and P. Lund. 2019. Effect of dried oregano (Origanum vulgare L.) plant material in feed on methane production, rumen fermentation, nutrient digestibility, and milk fatty acid composition in dairy cows. J. Dairy Sci. 102:9902-9918. https: //doi.org/10.3168/jds.2019-16329.

Plaizier, J. C., A. Martin, T. Duffield, R. Bagg, P. Dick, and B. W. McBride. 2000. Effect of a prepartum administration of monensin in a controlled-release capsule on apparent digestibilities and nitrogen utilization in transition dairy cows. J. Dairy Sci. 83:2918 2925. https://doi.org/10.3168/jds.S0022-0302(00)75192-7.

Skoula, M. R. J. Grayer, G. C. Kite, and N. C. Veitch. 2008. Exudate flavones and flavanones in Origanum species and their interspecific variation. Biochem. Syst. Ecol. 36:646-654. https://doi.org/ 10.1016/j.bse.2008.05.003

Skoula, M., and J. B. Harborne. 2002. The taxonomy and chemistry of Origanum. Pages 67-108 in Oregano: The Genera Origanum and
Lippia. S. E. Kintzios, ed. Taylor and Francis, London, UK and New York, NY.

Sukhija, P. S., and D. L. Palmquist. 1988. Rapid method for determination of total fatty acid content and composition of feedstuffs and feces. J. Agric. Food Chem. 36:1202-1206. https://doi.org/10 $.1021 /$ jf00084a019.

Tekippe, J. A., A. N. Hristov, K. S. Heyler, T. W. Cassidy, V. D. Zheljazkov, J. F. S. Ferreira, S. K. Karnati, and G. A. Varga. 2011. Rumen fermentation and production effects of Origanum vulgare L. leaves in lactating dairy cows. J. Dairy Sci. 94:5065-5079. https: //doi.org/10.3168/jds.2010-4095.

Van Soest, P. J., J. B. Robertson, and B. A. Lewis. 1991. Methods for dietary fiber, neutral detergent fiber, and non-starch polysaccharides in relation to animal nutrition. J. Dairy Sci. 74:3583-3597. https://doi.org/10.3168/jds.S0022-0302(91)78551-2.

Weatherburn, M. 1967. Phenol-hypochlorite reaction for determination of ammonia. Anal. Chem. 39:971-974. https://doi.org/10 $.1021 / \mathrm{ac} 60252 \mathrm{a} 045$

\section{ORCIDS}

C. Benchaar (으 https://orcid.org/0000-0002-8644-6892 